\title{
The Role of Memorable Tourism Experiences in the Relation between City Image and Visitor Engagement Toward Re-Visit Intention to Yogyakarta City
}

\author{
Ulfah Ahsanah ${ }^{1 *}$ and Yessy Artanti ${ }^{2}$
}

\section{ר.?}

\section{AFFILIATION}

1,2 Department of Management, Faculty of Economics, Universitas Negeri Surabaya, East Java, Indonesia

\section{*CORRESPONDENCE:}

ulfahahsanah0497@gmail.com

THIS ARTICLE IS AVAILABLE IN:

http://journal.umy.ac.id/index.php/mb

DOI: 10.18196/mabis.v12i1.9138

\section{CITATION:}

Ahsanah, U. \& Artanti, Y. (2021). The role of memorable tourism experiences in the relation between city image and visitor engagement toward re-visit intention to Yogyakarta city. Jurnal Manajemen Bisnis, 12(1), 56-70.

\section{ARTICLE HISTORY}

Received:

19 June 2020

Revised:

26 Aug 2020

26 Sep 2020

Accepted:

05 Oct 2020
Abstract:

Research Aims: The purpose of this paper is to analyze and discuss the influence of city image and visitor engagement on re-visit intention through memorable tourism experiences as a mediation variable.

Design/Methodology/Approach: The research sampling techniques used was nonprobability sampling by judgmental sampling methods. The respondents involved 220 visitors who had visited Yogyakarta city two times in the last two years. Path analysis was employed to analyze the data

Research Findings: The results showed that visitor engagement had no significant impact on re-visit intention, while city image and memorable tourism experiences significantly affected re-visit intention. Similarly, city image and visitor engagement significantly influenced memorable tourism experiences. Theoritical Contribution/ Originality: The empirical results of this study provide tenable evidence that the proposed Path analyse designed to consider city image visitor engagement, memorable tourism experience, and revisit intention simultaneously is acceptable, although the previous researchers have not explained the relationship between variables as a whole Practitioner/Policy Implication: The results of this study indicate that the city of Yogyakarta is able to sell and market the image of the city and its tourism performance related to culture well to tourists, so that tourists have long-term memorable memories related to the city of Yogyakarta, especially women aged 15-30 years, even though based on the research results there is no emotional attachment to tourists when traveling to Yogyakarta.

Research Limitation/Implication: In conducting this research, the researchers have limitations in data retrieval due to a COVID-19 outbreak that made many tourists not visiting tourist destinations, resulted in tourism-related groups even quieter and online questionnaires could not spread properly.

Keywords: City Image; Visitor Engagement; Memorable Touris Experiences; ReVisit Intention

\section{Introduction}

The tourism sector becomes a trend that always attracts the attention of every country in the world every year, including countries in the Asian region, one of which is Indonesia that has potential tourism resources. 


\author{
Ahsanah \& Artanti \\ The Role of Memorable Tourism Experiences in the Relation between City Image ...
}

The Ministry of Tourism (2019) recorded the growth of foreign tourist visits to ASEAN in 2018, and Indonesia became the second largest country visited by many foreign tourists with a percentage of $12.58 \%$ above Thailand, Singapore, and Malaysia (Databoks.katadata.co.id, 2019). The maximization of tourist destinations' potential in Indonesia also affected the increasing number of tourist trips; namely, in 2019, the number of domestic tourist trips was 275 million times, increased by 5 million from 2018, which reached 270 million times (Kemenpar, 2019). Yogyakarta is one of the cities in Indonesia that captures this phenomenon. With all the beauty, historical relics, and cultural attachments that can attract tourists, Yogyakarta has also experienced an increase in the number of visits. In 2018, there were 4,103,240 visitors, which increased by 208,469 visitors from 2017, which amounted to $3,894,771$ million visitors (BPS, 2018). Besides, in 2019, Yogyakarta managed to obtain the highest cultural development index (IPK) value of 73.79. This value could outperform Bali's IPK value of 65.3 (Jogjapolitan.harianjogja.com, 2019). Although Yogyakarta has succeeded in competing with Bali in terms of culture, based on TripAdvisor data summarized by Tirto.id site, in the same year, Yogyakarta was still inferior to Bali in terms of the most popular tourist destinations frequently visited by tourists, where Bali ranked first and Yogyakarta ranked third (www.Tirto.id, 2019). As recorded, tourists' engagement with all things, including fellow tourists in Bali, has a deeper meaning (www.phinemo.com). It strengthens the assumption that tourists have the intention to re-visit Bali compared to Yogyakarta.

In the long term, re-visits become an attractive market segment for tourist destinations, primarily due to considering the cost and effectiveness of art destination events as necessary for the tourism industry (Hasan, 2015:385). When determining future destination plans, travelers rely on previous experiences and memories to determine their next trip (Wirtz, Kruger, Scollon, \& Diener, 2003), and in recent years, research studies related to memorable tourism experiences are essential as an impact of tourism destination competition phenomenon (Kim \& Ritchie, 2014). According to Hidayah (2019), in his book, an experience is one of the internal factors that affect visitor behavior, as in Chen and Rahman's research (2018), which obtained results that memorable tourism experience positively impacted re-visit intention. In fact, there have been some studies suggesting that a memorable tourism experience did not directly influence tourists to visit again, such as research by Manthiou, Kang, Chiang, \& Tang (2016), which tested the impact of the amusement park visitor experience on loyalty. The result revealed that the experience affected traveler loyalty indirectly through satisfaction and memory.

Based on the field survey results, the Ministry of Tourism has also noted that tourists were more interested in visiting cultural tourism types with a percentage of $60 \%$, where one of the products was a city tour that obtained a percentage of $35 \%$ (Kemenpar, 2019). As Yananda and Salamah (2014) stated in his book, a positive image owned by a city is a kind of guarantee for businesspeople and investors of the certainty and development of their investment. However, in the face of an increasingly evolving era, cities must have strategies based on creativity rather than cultural and historical assets of the city itself so that visitors can feel a more memorable image of the city during and after their trip (Richards \& Wilson, 2006). 


\author{
Ahsanah \& Artanti \\ The Role of Memorable Tourism Experiences in the Relation between City Image ...
}

Hidayah (2019) mentions one of the psychological factors that influence a person in revisiting a destination, namely the engagement of a tourist to that destination. Some studies of tourism aspects have also noted the influence of visitor engagement motivation and visitor behavior (Devesa, Laguna, \& Palacios, 2010). Research by Bryce, Curran, O'Gorman, and Taheri (2014) affirms that when visitors consider a place as an object, visitors want to be associated in every process of activity of this attraction. Besides, visitors who often engaged with tourism objects (Kolar \& Zabkar, 2010) would be more committed to a place (Silva \& Correia, 2017); they will feel attached, which eventually result in an attachment process so that the tourists have an intention to re-visit the same destination.

This research aims to determine the direct effect of city image and visitor engagement towards memorable tourism experience and re-visit intention, and the direct effect of memorable tourism experience on re-visit intention. Therefore, this research is expected to make an essential contribution to the tourism sector actors (government, entrepreneur, etc.) in Yogyakarta in developing its tourism, so that in practice, it can make tourists more contribute to Yogyakarta city by re-visiting.

\title{
Literature Review and Hypotheses Development
}

According to Wulanjani \& Derriawan (2017), re-visit intention is a behavioral intention when customers want to re-visit a place or destination; they do a positive word of mouth, settle longer, and buy more than expected. Furthermore, according to Kozak (2001), the intention to re-visit is based on tourists' willingness to visit the same destination or other attractions in the same destination. In terms of the consumption process, there are three stages of a visitor's behavior, namely before the visit (pre-visit), during the visit, and postvisit Yuniawati \& Finardi (2016). In the long run, more than once tourism visits have proven to be cheaper than first-time visits and caused the tourism sector to grow sustainably. It relies heavily on tourists who re-visit the tourist sites (Um, Chon, \& Ro, 2006).

Many destinations range from a city/countryside to a region or even a country (Zhang, Wu, \& Buhalis, 2018). The city images are defined differently and are considered multidimensional concepts in existing studies, ranging from social psychology and political science to communication and business (Zhang et al., 2018). According to Boulding's research in Yananda and Salamah (2014), the city image is the image of all characteristics that arise in one's mind when someone thinks of the place. Another opinion was expressed in the study of Indriani \& Kuswoyo (2017) about the city image, which is the image of a city that formed in the people's minds because of the characteristic of the city.

According to Mossberg and Kleppe (2005), city image can be used interchangeably with destination image. What distinguishes them is a purpose used in the context of tourism that represents smaller objects, such as a tourism attraction within the city (Zhang et al., 2018). Their research mentioned that for international tourists, their perception of city or country image ranging from the environment, politics, economics, and society in the city 


\begin{abstract}
Ahsanah \& Artanti
The Role of Memorable Tourism Experiences in the Relation between City Image ...
\end{abstract}

or country impacted the form of an impressive tourist experience. Thus, the city image itself in the context of tourism refers to tourists' impression of the city. Besides, in their research, the city image had a positive effect on the memorable tourism experience. According to Kim \& Lee (2015) research, a match between the self-conception of city visitors and city image could increase the likelihood of tourists re-visiting the city, so that in their research, the image of a city had a direct positive effect on the intention to revisit. It is the same as the research results from Mujihestia, Troena, and Hussein (2018) that city image directly influenced re-visit intention.

$\boldsymbol{H}_{1}$ : City image has a positive effect on a memorable tourism experience.

$\boldsymbol{H}_{2}$ : City image has a positive effect on re-visit intention.

In the context of tourism, research related to visitor engagement has emerged through observation and experimentation techniques in capturing how much time tourists spent at a destination (Black, 2012; Falk \& Storksdieck, 2005). Patterson, Yu, and de Ruyter (2006) were the first researchers to raise the topic of the visitor engagement concept in the context of marketing and tourism. They consider the relationship between the customers' physical, cognitive, and emotional presence with the service company and take into account the customers' relationship as one of the increasing factors of order/visit. There are four components that affect namely, absorption (focus on a product/brand), dedication (a sense of belonging to the product/brand or place), vigor (energy level and mental endurance when interacting with objects or places), and interaction (two-way communication between consumers with objects or places).

Furthermore, according to Taheri, Jafari, and O'Gorman (2014), visitor engagement is a behavioral act through the quality of the attachment, emotional connection, commitment, and devotion of a tourist to the attraction. Based on Taheri et al. (2014) research, visitor engagement positively affected a memorable tourism experience, where a tourist related to a tour would produce an unforgettable experience. In the study of Loureiro and Sarmento (2019), visitor engagement positively affected the desire to return. It is in line with Alrawadieh, Prayag, Alrawadieh, and Alsalameen (2019) research, where visitor engagement positively correlated with the tourist intention to re-visit.

$\boldsymbol{H}_{3}$ : Visitor engagement has a positive effect on a memorable tourism experience.

$\boldsymbol{H}_{4}$ : Visitor engagement has a positive effect on re-visit intention.

The Memorable Tourism Experience (MTE) is defined as a tourism experience that is remembered positively after traveling (Kim, Ritchie, \& McCormick, 2012). However, the concept of memorable tourism experience and tourist experience are two different things. They are two things intertwined with each other but differ in the connotations and existence (Zhang et al., 2018). The tourist experience itself is a subjective mental state felt by visitors while feeling the services provided (Otto \& Ritchie, 2012). Meanwhile, the 
The Role of Memorable Tourism Experiences in the Relation between City Image ...

memorable tourism experience is a travel experience built selectively from the tourist experience and can be remembered after a destination trip (Zhang et al., 2018). Nevertheless, only a part of the tourism experience deeply affects the individual and causes memory to be considered in the concept of a Memorable tourism Experience (MTE). Similarly, the research of Barnes, Mattsson, and Sørensen (2016) suggested that experiences remembered in the long run had the most substantial effect on the intention to visit again. Supported by Zhang et al. (2018) research, Memorable Tourism Experience (MTE) positively affected re-visit intention.

$\boldsymbol{H}_{5}$ : Memorable Tourism Experience has a positive effect on re-visit intention.

Based on the hypothesis formed, the following conceptual framework was obtained:

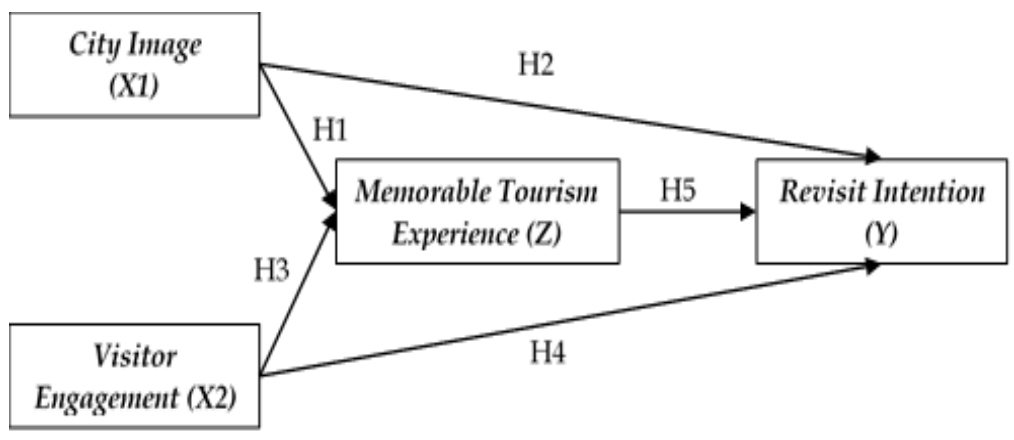

Figure 1 Conceptual Framework

\section{Research Methods}

This research is a quantitative study. The samples in this study were taken using nonprobability sampling techniques, employing a sampling judgmental according to the characteristics. In this study, the respondents were 220 . This research's population was tourists who had been traveling to Yogyakarta, with the characteristic of tourists aged 15 - 70 years, who had traveled to Yogyakarta city at least twice in the last two years (1 January 2018-1 April 2020). The measurement selected for this study was the Likert Scale. The data analysis technique utilized was path analysis.

The explanation of the variable measurement items used to measure city image, visitor engagement, memorable tourism experience, and re-visit intention that have been employed by some previous researchers and adopted by the current researchers can be seen in Table 1. 
The Role of Memorable Tourism Experiences in the Relation between City Image ...

Table 1 Measurement of Item `s Variables

\begin{tabular}{|c|c|c|}
\hline Variables & References & Items \\
\hline \multirow[t]{11}{*}{ City Image } & \multirow{11}{*}{$\begin{array}{l}\text { Kim \& Lee } \\
(2015)\end{array}$} & A suitable city for shopping \\
\hline & & A city with a lively and fun nightlife \\
\hline & & A city with a beautiful city setting to enjoy \\
\hline & & A city with exotic buildings \\
\hline & & A city that gives memories of historical relics \\
\hline & & A city that has many tourist attractions \\
\hline & & A city with a museum and art gallery \\
\hline & & Clean city \\
\hline & & Pleasant city atmosphere \\
\hline & & A city with a safe environment \\
\hline & & A city that can be used as a mainstay \\
\hline \multirow{10}{*}{$\begin{array}{l}\text { Visitor } \\
\text { Engagement }\end{array}$} & \multirow{10}{*}{$\begin{array}{l}\text { Rasoolimanesh } \\
\text { et al. (2019) }\end{array}$} & Emotionally tied with a tourist destination \\
\hline & & Enthusiastic about tourist destinations \\
\hline & & Anything related to tourist destinations attracts. \\
\hline & & Enjoying a truly sincere when a visit to tourist destinations \\
\hline & & Quick time to go when visiting tourist destinations \\
\hline & & Taking in the atmosphere when visiting tourist destinations \\
\hline & & $\begin{array}{l}\text { Feeling happy to interact with the same minded community } \\
\text { tourism }\end{array}$ \\
\hline & & $\begin{array}{l}\text { Enjoying exchanging thoughts with others in the community } \\
\text { of tourism sites }\end{array}$ \\
\hline & & Feeling bad when someone criticizes the tourist destination \\
\hline & & $\begin{array}{l}\text { Feeling like a compliment when someone praises this tourism } \\
\text { site }\end{array}$ \\
\hline \multirow{11}{*}{$\begin{array}{l}\text { Memorable } \\
\text { Tourism } \\
\text { Experience }\end{array}$} & \multirow{11}{*}{$\begin{array}{l}\text { Kim et al. } \\
\text { (2012); } \\
\text { Ghohary et al., } \\
\text { (2018); Zhang } \\
\text { et al. (2018) }\end{array}$} & Experiencing the thrill of fun during the destination trip \\
\hline & & Enjoying travel destination \\
\hline & & Having a unique experience at a tourist destination \\
\hline & & Experiencing something new during the trip \\
\hline & & Getting to know the local culture more closely \\
\hline & & Getting up close to the local culture of friendly locals \\
\hline & & Feeling free from all activities during the trip \\
\hline & & Feeling better after the trip \\
\hline & & A feeling of having done something meaningful during the trip \\
\hline & & Feeling self-understanding during the destination trip \\
\hline & & Acquiring new knowledge from the trip \\
\hline \multirow{3}{*}{$\begin{array}{l}\text { Re-visit } \\
\text { Intention }\end{array}$} & \multirow{3}{*}{$\begin{array}{l}\text { Bigné, } \\
\text { Sánchez, \& } \\
\text { Sánchez } \\
\text { (2001); Chang, } \\
\text { Su-Ching } \\
\text { (2006; in } \\
\text { (Chen \& } \\
\text { Rahman, } \\
\text { 2018) }\end{array}$} & Intention to recommend to other people \\
\hline & & Intention to re-visit \\
\hline & & Willing to place the visiting destination on priority \\
\hline
\end{tabular}

Source: Processed by researchers 
The Role of Memorable Tourism Experiences in the Relation between City Image ...

\section{Results and Discussion}

Based on this study's results, the researchers first conducted the validity and reliability tests of online questionnaires disseminated to 220 respondents. The validity and reliability test results can be seen in the following Table 2 .

Table 2 The Validity and Reliability Test Results

\begin{tabular}{|c|c|c|}
\hline Statement Items & Validity's Results & Reliability's Results \\
\hline \multicolumn{3}{|l|}{ City image (X1) } \\
\hline X1.1 & 0,544 & \multirow[t]{11}{*}{0,810} \\
\hline $\mathrm{X} 1.2$ & 0,593 & \\
\hline $\mathrm{X} 1.3$ & 0,545 & \\
\hline $\mathrm{X} 1.4$ & 0,604 & \\
\hline $\mathrm{X} 1.5$ & 0,565 & \\
\hline $\mathrm{X} 1.6$ & 0,576 & \\
\hline $\mathrm{X} 1.7$ & 0,595 & \\
\hline $\mathrm{X} 1.8$ & 0,565 & \\
\hline X1.9 & 0,691 & \\
\hline $\mathrm{X} 1.10$ & 0,596 & \\
\hline $\mathrm{X} 1.11$ & 0,630 & \\
\hline \multicolumn{3}{|l|}{ Visitor engagement (X2) } \\
\hline $\mathrm{X} 2.1$ & 0,701 & \multirow[t]{10}{*}{0,878} \\
\hline $\mathrm{X} 2.2$ & 0,627 & \\
\hline $\mathrm{X} 2.3$ & 0,713 & \\
\hline X2.4 & 0,654 & \\
\hline $\mathrm{X} 2.5$ & 0,657 & \\
\hline $\mathrm{X} 2.6$ & 0,682 & \\
\hline$\times 2.7$ & 0,708 & \\
\hline $\mathrm{X} 2.8$ & 0,757 & \\
\hline X2.9 & 0,726 & \\
\hline $\mathrm{X} 2.10$ & 0,748 & \\
\hline \multicolumn{3}{|c|}{ Memorable Tourism Experience ( $\mathrm{Z}$ ) } \\
\hline Z1.1 & 0,655 & \multirow[t]{13}{*}{0,902} \\
\hline $\mathrm{Z} 1.2$ & 0,669 & \\
\hline $\mathrm{Z1.3}$ & 0,683 & \\
\hline Z1.4 & 0,652 & \\
\hline $\mathrm{Z1.5}$ & 0,715 & \\
\hline Z1.6 & 0,558 & \\
\hline $\mathrm{Z1.7}$ & 0,677 & \\
\hline $\mathrm{Z1.8}$ & 0,736 & \\
\hline Z1.9 & 0,714 & \\
\hline Z1.10 & 0,717 & \\
\hline Z1.11 & 0,681 & \\
\hline Z1.12 & 0,716 & \\
\hline $\mathrm{Z} 1.13$ & 0,674 & \\
\hline \multicolumn{3}{|l|}{ Re-visit Intention (Y) } \\
\hline Y1.1 & 0,825 & \multirow[t]{3}{*}{0,718} \\
\hline Y1.2 & 0,778 & \\
\hline Y1.3 & 0,824 & \\
\hline
\end{tabular}

Source: Processed by researchers

The validity test results are valid when the coefficient between items and total items $\geqslant$ is 0.3 ; however, if the correlated value is $\leqslant 0.3$, it is declared invalid (Sugiyono, 2016). The validity test results showed that the whole item statement was valid because the $R$ - 
The Role of Memorable Tourism Experiences in the Relation between City Image ...

count value $\geqslant$ was 0.3 and positive. Besides, the reliability test results revealed that the overall variable's value was higher than Cronbach's alpha value of 0.70 . It could be stated that all the variables in the study were declared reliable. Furthermore, for the normality test, the results indicated that the C.R. skew's value was between the range of -2.58 to 2.58 .

This study had four classic assumptions: normality test, linearity test, outlier test, and multicollinearity test. The multivariate normality test value in the overall variable was 0.349 , which ranged from -2.58 to 2.58 . It could be said that the normality of multivariate assumptions had been fulfilled. Followed by the linearity test results, all variables had a probability value $(P)$, which was in the range $0,000<0.05$, so that the five variables had fulfilled the requirements and could be said to be linear. Besides, for the multicollinearity test results, the value generated from the sample covariance matrix's determinant was far from $0,4192.272$. Therefore, there could be no multicollinearity or singularity in this study. Subsequent model feasibility test obtained $71 \%$ of results. These results explained that the model's contribution to the variables' structural relationship: city image, visitor engagement, and memorable tourism experience to re-visit intention was $71 \%$, and the rest of $29 \%$ was explained by other variables not involved in the model.

Furthermore, based on the online questionnaire distributed, the researchers summarized the respondents' characteristics, as presented in Table 3.

Table 3 Respondents' Characteristics

\begin{tabular}{|c|c|c|}
\hline Respondents' Characteristics & Amount & Percentage \\
\hline \multicolumn{3}{|l|}{ Gender } \\
\hline Man & 87 & $39,5 \%$ \\
\hline Woman & 133 & $60,5 \%$ \\
\hline \multicolumn{3}{|l|}{ Age } \\
\hline $15-30$ years & 192 & $87,3 \%$ \\
\hline 31 - 45 years & 18 & $8,2 \%$ \\
\hline $46-60$ years & 9 & $4,1 \%$ \\
\hline $61-70$ years & 1 & $0,5 \%$ \\
\hline \multicolumn{3}{|l|}{ Profession } \\
\hline General Employees & 32 & $14,5 \%$ \\
\hline Government Employees & 18 & $8,2 \%$ \\
\hline Entrepreneur & 18 & $8,2 \%$ \\
\hline Student/College Student & 129 & $58,6 \%$ \\
\hline Other & 23 & $10,5 \%$ \\
\hline \multicolumn{3}{|l|}{ Income/ Month } \\
\hline$<$ Rp 1.500 .000 & 48 & $21,8 \%$ \\
\hline $\operatorname{Rp} 1.500 .000-\operatorname{Rp} 3.000 .000$ & 97 & $44,1 \%$ \\
\hline Rp 3.000.001 - Rp 4.500.000 & 35 & $15,9 \%$ \\
\hline $\operatorname{Rp} 4.500 .001-\operatorname{Rp} 6.000 .000$ & 23 & $10,5 \%$ \\
\hline$>\operatorname{Rp} 6.000 .000$ & 17 & $7,7 \%$ \\
\hline \multicolumn{3}{|l|}{ Number of Visits } \\
\hline 2 times & 92 & $41,8 \%$ \\
\hline 3 times & 58 & $26,4 \%$ \\
\hline 4 times & 26 & $11,8 \%$ \\
\hline$>4$ times & 44 & $20 \%$ \\
\hline
\end{tabular}

Source: Processed by researchers 


\begin{abstract}
Ahsanah \& Artanti
The Role of Memorable Tourism Experiences in the Relation between City Image ...
\end{abstract}

Table 3 shows that most respondents in this study were female, the age ranged from 1530 years old, worked as students, had income between Rp. 1.500.000-Rp.3.000.000, and had visited Yogyakarta City two times in the last two years. In From Table 3, overall, it could be concluded that many respondents visited Yogyakarta City more than once because of the pleasant cultural atmosphere of Yogyakarta and the many tourist objects with a cheap budget that were attractive to tourists, especially for women who often traveled to places with many photo spots and tourist places with cheap budgets.

Path analysis test in this study presented the hypothesis test results in Table 4:

Table 4 The Hypothesis Test Results

\begin{tabular}{|c|c|c|c|c|c|c|}
\hline & & & Estimate & C.R & P & Description \\
\hline $\begin{array}{c}\text { Memorable Tourism } \\
\text { Experience }\end{array}$ & 4 & City Image & ,417 & 9,684 & ,000 & Supported \\
\hline Re-visit Intention & $\leftarrow$ & City Image & ,306 & 4,661 & ,000 & Supported \\
\hline $\begin{array}{c}\text { Memorable Tourism } \\
\text { Experience }\end{array}$ & 4 & $\begin{array}{c}\text { Visitor } \\
\text { Engagement }\end{array}$ & ,646 & 15,008 & ,000 & Supported \\
\hline Re-visit Intention & 4 & $\begin{array}{c}\text { Visitor } \\
\text { Engagement }\end{array}$ & 152 & 1,994 & , 052 & $\begin{array}{c}\text { Not } \\
\text { Supported }\end{array}$ \\
\hline Re-visit Intention & $\longleftarrow$ & $\begin{array}{c}\text { Memorable } \\
\text { Tourism } \\
\text { Experience }\end{array}$ & 290 & 4,375 & , 000 & Supported \\
\hline
\end{tabular}

Source: Processed by researchers

According to Table 4, it was obtained that $\mathrm{H}_{1}, \mathrm{H}_{2}, \mathrm{H}_{3}$, and $\mathrm{H}_{5}$ were accepted because they had a calculated C.R. value $\geqslant$ of 2.00 and a significance value $(P)$ of $\leqslant 0.05$. Meanwhile, $\mathrm{H}_{4}$ was rejected because the calculated $C$. $R$. was $\leqslant 2.00$, and the significance value $(P)$ was $\geqslant 0.05$. Besides, based on the overall test results in standardized direct effects, standardized indirect effects, and standardized total effects, the value obtained from standardized direct effects of city image and visitor engagement on memorable tourism experience was higher than the direct influence value of the city image and visitor engagement on re-visit intention. It denoted that the memorable tourism experience variable could not be stand-alone and became a mediation variable. Meanwhile, this research's mediation test result uncovered that a memorable tourism experience partially mediated the city image on the re-visit intention. This result was due to the significant influence of city image on re-visit intention with a value of 0.224 . After adding the memorable tourism experience, the value of city image's influence on re-visit intention decreased by 0.112 above 0.000 . Meanwhile, a memorable tourism experience had visitor engagement to re-visit intention perfectly. This result was because of the significant influence of visitor engagement on re-visit intention with a value of 0.159 . Then, after the memorable tourism experience had been added, the value of the impact's visitor engagement on the re-visit intention decreased by 0.057 , close to 0.000 .

Furthermore, this study's mediation hypothesis test could be done by the procedure developed by Sobel (1982) and is known as Sobel Test (Ghozali, 2016). When the probability of significance is 0.0001 ( $P \leqslant 0.05)$, it can be said that there is a mediation effect (Ghozali, 2016). Based on the Sobel test results in this research, the mediation 


\author{
Ahsanah \& Artanti \\ The Role of Memorable Tourism Experiences in the Relation between City Image ...
}

variable of memorable tourism experience had a value of $0.00 \leqslant 0.05$. It was concluded that overall, memorable tourism experience $(Z)$ was proved to mediate the city image (X1) relationship with re-visit intention $(Y)$ and the visitor engagement $(X 2)$ relationship with re-visit intention $(\mathrm{Y})$.

According to the analysis results that have been done, this research exposed that the city image positively affected a memorable tourism experience. It signified that the greater the city image of Yogyakarta City in tourists' minds, it would affect the magnitude of an impressive tourist's experience the Yogyakarta City. Based on these results, the first hypothesis was accepted and supported the truth of the city image theory according to the research of Zhang et al. (2018). It mentions that the city image refers to the traveler's impression of the city itself that will be remembered; when international tourists visit a country or city, their perception of the city or country image starts from the environment, politics, economics, and society, influencing of an impressive travel experience. In addition to the theory, the study results also support the research results by Zhang et al. (2018), where the city image had a positive effect on memorable tourism experience. This result is in accordance with the fact that Yogyakarta City has succeeded in building a city image through its cultural preservation, as shown by acquiring the highest Cultural Assessment Index in Indonesia in 2019. It can be seen starting from old buildings, such as palaces, temples, and other old buildings, and the atmosphere of the night city of Yogyakarta in Malioboro. Therefore, tourists visiting Yogyakarta City have an impressive experience in their minds.

Besides, the relationship between city image and re-visit intention in this research also had a positive effect. The better the image of Yogyakarta, the desire of tourists to visit again also higher. The result is in agreement with the second hypothesis that "city image has a positive effect on re-visit intention" on tourists who had traveled to Yogyakarta City. It also supports the city image theory, stating that the city image is a comprehensive image of perception and evaluation of visitors to the goal of everyone in the city regarding the history, geography, culture, politics, economics, and the development of the city itself (Carneiro \& Faria, 2016). Besides, cities with positive images are more taken into account in the context of competition with other cities (Yananda \& Salamah, 2014). Thus, the match between a visitor's self-conception to the city and the city's image can increase tourists' likelihood of re-visiting the city (Kim \& Lee, 2015).

Moreover, to support some experts' theory, the study results also reinforce the research results by Mujihestia et al. (2018) and Kim \& Lee (2015), which found a direct positive effect of city image on re-visit intention. The explanation is in line with increasing visitors to Yogyakarta city from 2017 to 2018, where tourists who have visited Yogyakarta city did more than once travel. The Yogyakarta city has also managed to sell its tourism performance to tourists by having many tourist attractions and unique things in Yogyakarta, which are highlighted, such as seeing the process of making bakphia pathok, the advantages of typical batik, thick Javanese customs, to the many awards of Yogyakarta city in the field of tourism. Therefore, it leads to the positive image of Yogyakarta City, which has attached in tourists' minds so that tourists want to re-visit Yogyakarta in the future. 


\author{
Ahsanah \& Artanti \\ The Role of Memorable Tourism Experiences in the Relation between City Image ...
}

Furthermore, this research's results are consistent with the third hypothesis that visitor engagement was positively influential to the memorable tourism experience. It signified that the higher the tourists' engagement with everything in Yogyakarta city, the more memorable memories that are unforgettable during a visit to Yogyakarta city. This study's results corroborate the research results of Bryce et al. (2014) that the meaning of engagement is regarded as the interactive process of tourists connected with involvement and the commitment developed by tourists in the consumption experience (tourism attractions) (Brodie, Hollebeek, Jurić, \& Ilić, 2011). Moreover, the visitor engagement theory is an act of behavior through the quality of the attachment, emotional connection, commitment, and devotion of a tourist to the attraction (Taheri et al., 2014). Thus, it can be interpreted that when tourists feel the attachment and emotional connection to tourist destinations, then tourists will feel a memorable experience, which will later be remembered after the trip. Based on some of these studies' results, it could be said this study's results are supported, and it could be concluded that the connection of tourists to an object would make tourists have unforgettable memories. This study's results also support the previous research results from Taheri et al. (2014), which discovered a positive influence of visitor engagement on memorable tourism experiences. In accordance with the fact, all the tourists' attachment to tourism objects in Yogyakarta city rich in culture has fully provided a memorable experience to tourists who visit. It was proven in 2019, Yogyakarta city could rank number 3 as the most popular tourist destination in Indonesia.

The next research result is that visitor engagement did not affect re-visit intention. Although tourists' attachment to the city of Yogyakarta increased or decreased, it could not influence the re-visit intention. According to Bryce et al. (2014), when a visitor considers a place as an object, the visitor wants to be attributed in every process of activities from that attraction, and the engagement will be regarded as an intention to say positive things, recommend, and use object attachment (Harrigan, Evers, Miles, \& Daly, 2017). Besides, visitors who are often involved with tourist attractions (Kolar \& Zabkar, 2010) will be more committed to a place (Silva \& Correia, 2017), feel bound and produce an attachment process they want to re-visit it. Based on this research result stating that visitor engagement negatively influenced and did not impact re-visit intention, the theory is not supported. This study's results also reject the research of Loureiro and Sarmento (2019) and Alrawadieh et al. (2019), which asserted that visitor engagement was positively influential to re-visit intention. In fact, Yogyakarta city can still not make tourists entirely tied to everything in Yogyakarta city. The Yogyakarta culture has not been able to bind tourists so that tourists reconsider to visit Yogyakarta city despite the cultural assessment index of Yogyakarta (IPK) in the year 2019 was the highest in Indonesian, namely the tourist destinations in Yogyakarta City, especially in terms of visitor bonding. It was because tourists only enjoyed Yogyakarta City's atmosphere without being emotionally involved with Yogyakarta, and Yogyakarta City lacked the tourists in the direct dive enjoying the Javanese culture in the city of Yogyakarta.

Then, a memorable tourism experience positively influenced re-visit intention. The bigger memorable memories are unforgettable during the trip to Yogyakarta City, the greater intention to re-visit. It is in tune with research by Barnes et al. (2016), Zhang et al. (2018), 


\author{
Ahsanah \& Artanti \\ The Role of Memorable Tourism Experiences in the Relation between City Image ...
}

and Chen and Rahman (2018), which uncovered that a memorable tourism experience had a positive impact on re-visit intention. In their research, Barnes et al. (2016) also said that the long-term experience of being remembered is the most powerful effect in the intention of visiting again. The atmosphere of Yogyakarta made tourists stay longer and did various holiday activities in Yogyakarta city to create a memorable experience that would be remembered by tourists for an extended period. It was evidenced by the number of tourists to Yogyakarta in 2017 - 2018, which has increased due to the revisitation of tourists.

\title{
Conclusion
}

This research has proven that the city image was positively influential to re-visit intention. However, for visitor engagement, it did not affect re-visit intention. Then, the city image was proved to be directly and positively influential on the memorable tourism experience. Similarly, visitor engagement had a positive effect on the memorable tourism experience. Thus, this research revealed the importance of city image, visitor engagement, and memorable tourism experience in forming re-visit intention tourists. Besides, the role of a memorable tourism experience can also increase re-visit intention.

In conducting this research, the researchers have limitations in data retrieval due to a COVID-19 outbreak that made many tourists not visiting tourist destinations, resulted in tourism-related groups even quieter and online questionnaires could not spread properly. However, the researchers continued to conduct a group search that was still crowded discussing tourism-related issues. Other limitations are the lack of variable related theories so that researchers have limitations in the deep-dive variables. Advice for further researchers is to deepen the related variables tested both from theory to gap with other variables and further expands the spread of online questionnaire related research objects. Furthermore, although from the research results, some variables related to Yogyakarta city were positive because of the magnitude of public response to the city of Yogyakarta and the increasing visitors of Yogyakarta City year after year, throughout the year 2020, COVID-19 emerged, making the tourism industry experienced much decline in the number of tourists. However, businesspeople in this sector are expected to continue to be optimistic and see the crisis as opportunities later. Moreover, the government's role is required in restoring the national economy and the spirit of businesspeople, especially in the tourism sector. Regardless of current conditions, tourist destinations need to continue to conduct online communication or promotion related to tourist destinations because good response from the community will be a preparatory effort after the crisis.

\section{References}

Alrawadieh, Z., Prayag, G., Alrawadieh, Z., \& Alsalameen, M. (2019). Self-identification with a heritage tourism site, visitors' engagement and destination loyalty: the mediating effects of overall satisfaction. The Service Industries Journal, 39(7-8), 541-558. https://doi.org/10.1080/02642069.2018.1564284

Badan Pusat Statistik (BPS). (2018). Statistik Kepariwisataan DIY 2018. 
The Role of Memorable Tourism Experiences in the Relation between City Image ...

Barnes, S. J., Mattsson, J., \& Sørensen, F. (2016). Remembered experiences and revisit intentions: A longitudinal study of safari park visitors. Tourism Management, 57, 286-294. https://doi.org/10.1016/j.tourman.2016.06.014

Bigné, J. E., Sánchez, M. I., \& Sánchez, J. (2001). Tourism image, evaluation variables and after purchase behaviour: inter-relationship. Tourism Management, 22(6), 607-616. https://doi.org/10.1016/s0261-5177(01)00035-8

Black, G. (2012). Transforming museums in the 21st Century. London: Routledge.

Brodie, R. J., Hollebeek, L. D., Jurić, B., \& Ilić, A. (2011). Customer engagement: Conceptual domain, fundamental propositions, and implications for research. Journal of Service Research, 14(3), 252-271. https://doi.org/10.1177/1094670511411703

Bryce, D., Curran, R., O'Gorman, K., \& Taheri, B. (2015). Visitors' engagement and authenticity: Japanese heritage consumption. Tourism Management, 46, 571-581. https://doi.org/10.1016/j.tourman.2014.08.012

Carneiro, J., \& Faria, F. (2016). Quest for purposefully designed conceptualization of the country-of-origin image construct. Journal of Business Research, 69(10), 4411-4420. https://doi.org/10.1016/i.jbusres.2015.12.075

Chen, H., \& Rahman, I. (2018). Cultural tourism: An analysis of engagement, cultural contact, memorable tourism experience and destination loyalty. Tourism Management Perspectives, 26, 153-163. https://doi.org/10.1016/j.tmp.2017.10.006

Databoks.katadata.co.id. (2019). Indonesia masih menarik sebagai tujuan wisatawan mancanegara. Retrieved from: https://databoks.katadata.co.id/datapublish/2019/07/04/indonesia-masih-menariksebagai-tujuan-wisatawan-mancanegara

Devesa, M., Laguna, M., \& Palacios, A. (2010). The role of motivation in visitor satisfaction: Empirical evidence in rural tourism. Tourism Management, 31(4), 547-552. https://doi.org/10.1016/j.tourman.2009.06.006

Falk, J., \& Storksdieck, M. (2005). Using the contextual model of learning to understand visitor learning from a science center exhibition. Science Education, 89(5), 744-778. https://doi.org/10.1002/sce.20078

Ghozali, I. (2016). Aplikasi Analisis Multivariate dengan Program IBM SPSS 23 (Edisi 8). Semarang: Badan Penerbit Universitas Diponegoro

Harrigan, P., Evers, U., Miles, M., \& Daly, T. (2017). Customer engagement with tourism social media brands. Tourism Management, 59, 597-609. https://doi.org/10.1016/j.tourman.2016.09.015

Hasan, A. (2015). Tourism Marketing (T. CAPS, Ed.). Yogyakarta: CAPS (Center For Academic Publishing Service).

Hidayah, N. (2019). Pemasaran Destinasi Pariwisata (1st ed.). Palembang: Alfabeta.

Indriani, J., \& Kuswoyo, C. (2017). Pengaruh city branding pada city image dan keputusan berkunjung wisatawan ke Kabupaten Purwakarta. Jurnal Manajemen Maranatha, 17(1), 41. https://doi.org/10.28932/jmm.v17i1.410

Jogjapolitan.harianjogja.com. (2019). Selamat indeks pembangunan budaya di DIY tertinggi se-Indonesia. Retrieved from:

https://jogjapolitan.harianjogja.com/read/2019/10/11/510/1021660/selamat-indekspembangunan-budaya-di-diy-tertinggi-se-indonesia

Kementerian Pariwisata RI. (2019). Renstra Kementerian Pariwisata 2015-2019.

Kim, H., \& Lee, S. (2015). Impacts of city personality and image on revisit intention. International Journal of Tourism Cities, 1(1), 50-69. https://doi.org/10.1108/ijtc-08-2014$\underline{0004}$

Kim, J. H., \& Ritchie, J. R. B. (2014). Cross-cultural validation of a Memorable Tourism Experience Scale (MTES). Journal of Travel Research, 53(3), 323-335. 
The Role of Memorable Tourism Experiences in the Relation between City Image ...

https://doi.org/10.1177/0047287513496468

Kim, J. H., Ritchie, J. R. B., \& McCormick, B. (2012). Development of a scale to measure memorable tourism experiences. Journal of Travel Research, 51(1), 12-25. https://doi.org/10.1177/0047287510385467

Kolar, T., \& Zabkar, V. (2010). A consumer-based model of authenticity: An oxymoron or the foundation of cultural heritage marketing? Tourism Management, 31(5), 652-664. https://doi.org/10.1016/j.tourman.2009.07.010

Kozak, M. (2001). Repeater's behavior at two distinct destinations. Annals of Tourism Research, 28(3), 784-807. https://doi.org/10.1016/s0160-7383(00)00078-5

Loureiro, S. M. C., \& Sarmento, E. M. (2019). Place attachment and tourist engagement of major visitor attractions in Lisbon. Tourism and Hospitality Research, 19(3), 368-381. https://doi.org/10.1177/1467358418761211

Manthiou, A., Kang, J., Chiang, L., \& Tang, L. (2016). Investigating the effects of memorable experiences: An extended model of script theory. Journal of Travel and Tourism Marketing, 33(3), 362-379. https://doi.org/10.1080/10548408.2015.1064055

Mossberg, L., \& Kleppe, I. A. (2005). Country and destination image - different or similar image concepts? Service Industries Journal, 25(4), 493-503. https://doi.org/10.1080/02642060500092147

Mujihestia, T. I., Troena, E. A., \& Hussein, A. S. (2018). The role of city image and visitors, satisfaction the role of city image and visitors, satisfaction on visitors, revisit intention: a study in an enclave city. Journal of Applied Management (JAM), 16(36), 309-320. https://doi.org/10.21776/ub.jam.2018.016.02.14

Otto, J. E., \& Ritchie, J. R. B. (1996). The service experience in tourism. Tourism Management, 17(3), 165-174. https://doi.org/10.1016/0261-5177(96)00003-9

Patterson, P., Yu, Y., \& de Ruyter, K (2006). Understanding customer engagement in services, advancing theory, maintaining relevance. Proceedings of ANZMAC 2006 Conference, Brisbane, 4-6 December.

Phinemo.com. (2020). Ini alas an mengapa bali raih gelar destinasi wisata terbaik dunia. Retrieved from https://phinemo.com/ini-alasan-mengapa-bali-raih-gelar-destinasiwisata-terbaik-dunia

Rasoolimanesh, S. M., Md Noor, S., Schuberth, F., \& Jaafar, M. (2019). Investigating the effects of tourist engagement on satisfaction and loyalty. The Service Industries Journal, 39(7-8), 559-574. https://doi.org/10.1080/02642069.2019.1570152

Richards, G., \& Wilson, J. (2006). Developing creativity in tourist experiences: A solution to the serial reproduction of culture? Tourism Management, 27(6), 1209-1223. https://doi.org/10.1016/j.tourman.2005.06.002

Silva, R., \& Correia, A. (2017). Places and tourists: ties that reinforce behavioural intentions. Anatolia, 28(1), 14-30. https://doi.org/10.1080/13032917.2016.1240093

Sugiyono. (2016). Metode penelitian kuantitatif kualitatif dan kombinasi (mixed methods). Bandung: ALFABETA.

Taheri, B., Jafari, A., \& O’Gorman, K. (2014). Keeping your audience: Presenting a visitor engagement scale. Tourism Management, 42, 321-329. https://doi.org/10.1016/j.tourman.2013.12.011

Tirto.id. (2019). Daftar 10 kota wisata indonesia terpopuler 2019 versi tripadvisor. Retrieved from: https://tirto.id/daftar-10-kota-wisata-indonesia-terpopuler-2019-versitripadvisor-epEc

Um, S., Chon, K., \& Ro, Y. H. (2006). Antecedents of revisit intention. Annals of Tourism Research, 33(4), 1141-1158. https://doi.org/10.1016/j.annals.2006.06.003

Wirtz, D., Kruger, J., Scollon, C. N., \& Diener, E. (2003). What to do on Spring Break? The Role of Predicted, on-Line, and Remembered Experience in Future Choice. Psychological 
Ahsanah \& Artanti

The Role of Memorable Tourism Experiences in the Relation between City Image ...

Science, 14(5), 520-524. https://doi.org/10.1111/1467-9280.03455

Wulanjani, H., \& Derriawan, D. (2017). Dampak utilitarian value dan experiential marketing terhadap customer satisfaction dan revisit intention. Jurnal Riset Manajemen dan Bisnis (JRMB) Fakultas Ekonomi UNIAT, 2(2), 121-130.

https://doi.org/10.36226/jrmb.v2i2.42

Yananda, M. R. \& Salamah, U. (2014). Branding tempat: Membangun kota, kabupaten, dan provinsi berbasis identitas. Jakarta: Makna Informasi.

Yuniawati, Y., \& Finardi, A. D. I. (2016). Pengaruh customer experience terhadap revisit intention di taman wisata alam gunung tangkuban perahu. The Journal: Tourism and Hospitality Essentials Journal, 6(1), 983. https://doi.org/10.17509/thej.v6i1.2009

Zhang, H., Wu, Y., \& Buhalis, D. (2018). A model of perceived image, memorable tourism experiences and revisit intention. Journal of Destination Marketing \& Management, 8, 326336. https://doi.org/10.1016/j.jdmm.2017.06.004 